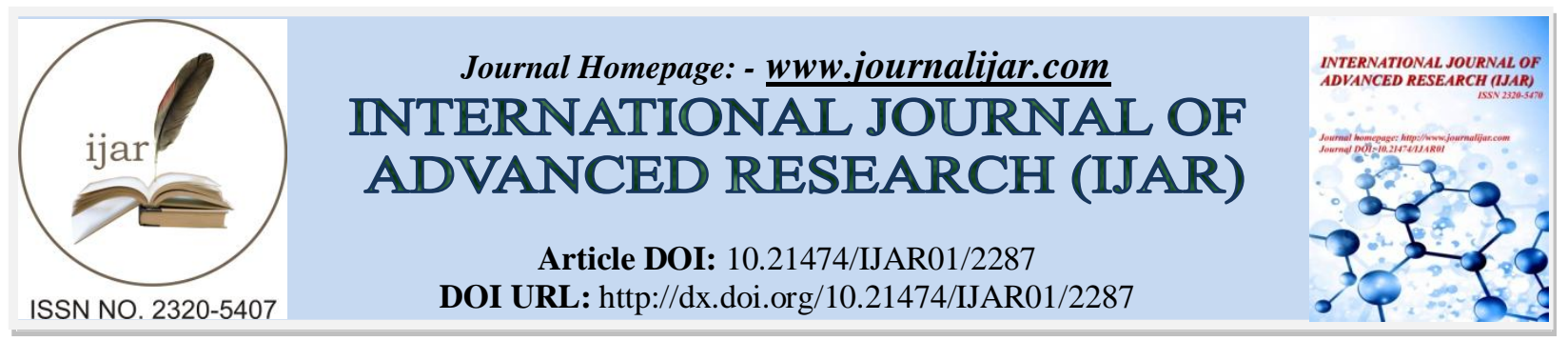

RESEARCH ARTICLE

\title{
FIRST REPORT AND SPATIAL DISTRIBUTION PATTERN OF THE SEWAGE SNAILS PHYSA ACUTA DRAPARNAUD, 1805 (GASTROPODA: PHYSIDAE) IN MAN-MADE LAKE SYSTEM OF YAMOUSSOUKRO (COTE D'IVOIRE, WEST AFRICA).
}

\author{
Bony Kotchi Yves ${ }^{1 *}$, Allouko Jean Renaud ${ }^{1}$, Konan Koffi Felix ${ }^{1}$, Edia Oi Edia ${ }^{2}$, Sylla Idrissa ${ }^{1}$ and Assemian \\ $\mathbf{N}^{\prime}$ guessan Emmanuel ${ }^{1}$. \\ 1. Departement of Environment, University Jean Lorougnon Guede, BP 150 Daloa, Ivory Coast. \\ 2. Laboratoire d'Environnement et de Biologie Aquatique, U.F.R.-S.G.E., Universite Nangui Abrogoua, 02 BP \\ 801 Abidjan 02, Cote d'Ivoire.
}

\section{Manuscript Info}

Manuscript History

Received: 29 September 2016

Final Accepted: 30 October 2016

Published: November 2016

Key words:-

Physa acuta, first report, sewage snail,

Yamoussoukro, Ivory Coast.

\section{Abstract}

A vital population of Physa acuta, a globally invasive species of freshwater gastropods was reported in Ivory Coast. Species identity was confirmed by conchological and anatomical methods. The occurrence of this population seems to be restricted to a single disturbed urban lake at Yamoussoukro, and physids occured in great abundances in this polluted lake. Physa acuta was associated with important amount of conductivity and TDS, and greater values of Fecal Coliforms. It likely that the species will further spread via active and/or passive dispersal across large distances, enhanced by environmental change.

Copy Right, IJAR, 2016,. All rights reserved.

\section{Introduction:-}

Physidae represent a family of freshwater pulmonate gastropods with a current worldwide distribution that has been, at least partly, the result of intensive introductions and subsequent invasions (Taylor, 2003). The arguably most well-known example is the invasive freshwater snail Physa acuta (Draparnaud, 1805), originates from Eastern North America (Dillon et al., 2002) and originally described from the Garonne River of France.

P. acuta has high dispersal ability; it is now common in certain parts of Australia (Madsen and Frandsen, 1989) and southern America (Paraense, 2005). In Asia, P. acuta has been recorded from Arabia (Brown and Wright, 1980; Magzoub and Kasim, 1980), Jordan (Burch, 1985), Sinaï (Tchernov, 1971) Iran, Iraq, Israel, Japan, Macao (Madsen and Frandsen, 1989), Malaysia (Ali, 1993) and India (Raut et al., 1995). It has also been reported from Africa including Madagascar (Brygoo, 1968; Hamilton-Atwell et al., 1970; Mandahl-Barth et al., 1974; Brown, 1965; 1980; 1994, Dupouy and Mimpfoundi, 1986; De Clercq, 1987; Clark et al., 1989; De Kock et al., 1989; Clark and Baroudy, 1990; Curtis, 1991; Brackenbury and Appleton, 1993; Appleton, 2003). In all these areas P. acuta is a common inhabitant of ponds, streams, river, rice fields and municipality drains (Macha, 1971; Brown, 1980; Godan, 1983; Alexandrawicz, 1986; Appleton and Bailey, 1990; Ali, 1993; Brackenbury and Appleton, 1993; Raut et al., 1995).

In West Africa, P. acuta has been reported only from Nigeria (Fashuyi, 1990; Kristensen and Ogunnowo, 1992). Several surveys carried out in Ivory Coast in the 20th century failed to report the presence of physid snails (Germain, 1908; 1911; Franc, 1949; Binder, 1957; Ndamkou, 1985; Mouchet et al., 1987; Yapi, 1988; N’Goran, 
1997). Though, most major freshwater habitat types in Ivory Coast are prone to Physa acuta invasions, so far there has been no report of this species in this country, until our first record of occurrence in Yamoussoukro man-made lakes.

Here, $(i)$ we report on the occurrence of a vital population of $P$. acuta in man-made Lakes of Yamoussoukro. Specie identity was confirmed by morphological and anatomical methods, and (ii) the spatial distribution pattern is presented in this paper.

\section{Materials and method:-}

\section{Study area;-}

The study was conducted in the political capital of Ivory Coast (Yamoussoukro; central Ivory Coast). This country is characterized by 11 lakes built in the 1970s communicating with each other by gravity; these lakes constitute an important touristic and cultural asset to this city. The study area lies between 6 $48^{\prime} 29^{\prime \prime}-6^{\circ} 49^{\prime} 50^{\prime \prime} \mathrm{N}$ and $5^{\circ} 15^{\prime} 55^{\prime \prime}-$ $5^{\circ} 17^{\prime} 24^{\prime \prime} \mathrm{W}$. This lake complex is covering an area of approximately 140 ha with a catchment area near $28.5 \mathrm{~km}^{2}$. However, they are completely flooded by aquatic plants, with the exception of three lakes (II, III and IV; Fig. 1). This eutrophication is attributable to basins land use, the activities developed on the watersides and the riverians habit. Indeed, the man-made lakes of Yamoussoukro receive important quantities of erosion products and waste (domestic waste, oil, sewage, sludge drain). Besides, they attend the modification of the water balance sheet linked to the hydrologic and hydrodynamic modification of lakes, to the increased sedimentation and physicochemical pollution of the lakes.

\section{Species discovery and identification:-}

A field study on the mollusc fauna of Yamoussoukro was conducted during three months with sampling on 9 out of 11 Lakes. A total of 21 sampling points (Fig. 1) in the lake yielded extensive mollusc material. Voucher specimens of Physa acuta were deposited at the University of Daloa; Ivory Coast), in the Ecole Pratique des Hautes Etudes of Perpignan (Laboratoire de Biologie Marine et Malacologie; France) and in the Centre d'Ecologie Fonctionnelle et Evolutive (CEFE Montpellier; France).

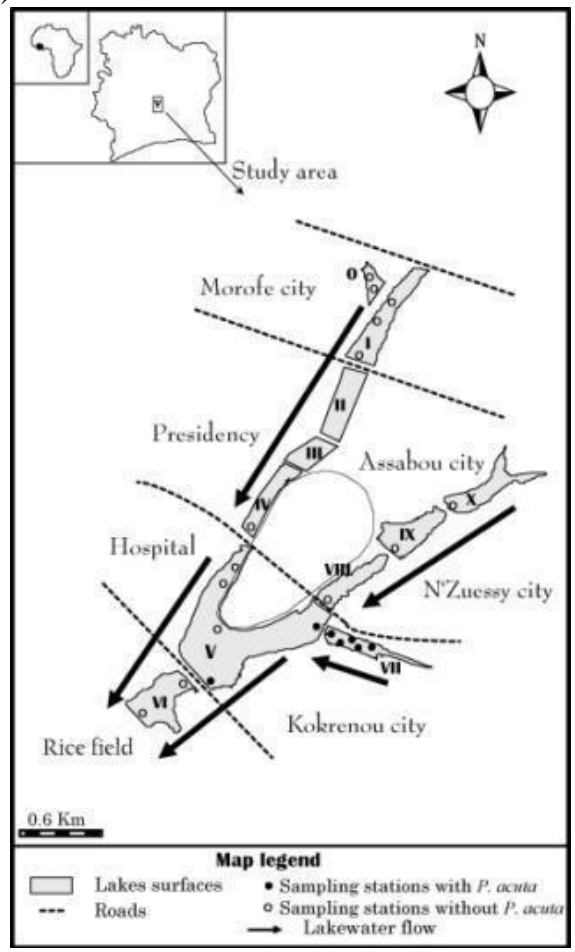

Fig. 1: Map of man-made lake system of Yamoussoukro with the location of the sampling stations and distribution of Physa acuta. Lakes were identified by roman numbers (0 to $\mathrm{X})$.

Snails were collected in water bodies of the lake complex using a long-handled sieve (mesh size $1 \mathrm{~mm}$ ) and transferred to the laboratory alive. The adult specimens were allowed to relax overnight using menthol. They were 
then immersed for 40 seconds in water heated at $70{ }^{\circ} \mathrm{C}$, from which they were transferred to water at room temperature. Soft parts were drawn from the shell using a small forceps and fixed in slightly modified Railliet-Henry fluid (distilled water $930 \mathrm{ml}$, sodium chloride $6 \mathrm{~g}$, formalin $50 \mathrm{ml}$, glacial acetic acid $20 \mathrm{ml}$ ). Shell width and height were measured to the nearest $0.1 \mathrm{~mm}$ using calipers. The larger snails (up to 25 specimens) were dissected under stereomicroscope for morphological and anatomical study.

\section{Spatial distribution pattern:-}

The field work included all major habitat types in the 9 lakes. Snails were collected monthly during five months (covering all seasons) by removing them from vegetation and mud using long-handled sieves (mesh size $1 \mathrm{~mm}$ ). Specimens were preserved in $96 \%$ ethanol, which was changed completely after 24 hours. All snails were sorted, identified with morphological characters and counted.

\section{Environmental variables:-}

The sampling sites were characterized by measuring in situ selected physical parameters using a multiparameter apparatus (WTW 840i). These were water temperature $\left({ }^{\circ} \mathrm{C}\right)$, conductivity $(\mu \mathrm{S} . \mathrm{cm}-1)$ and $\mathrm{pH}$. Total Dissolved Solid and Turbidity were measured with Turbidimeter WTW Turb 430R. Samples for chemical analyses were collected from each station using prewashed polyethylene bottles. The water samples were kept at a temperature below $4{ }^{\circ} \mathrm{C}$ to stop all the activities and metabolism of the organisms in the water and were analyzed within 24 hours after collection. Afterward, the concentrations of nitrite, nitrate, ammonium, phosphate, sulfate, chlorure, iron, calcium and manganese were determined in the laboratory according to standard spectro-photometric methods by using a spectrophotometer SCHIMADZU UV 160A. Total Fecal Coliform (10/100mL) was also determined.

\section{Data analysis:-}

We used the Kruskal-Wallis and Mann-Whitney non-parametric tests to search for potential differences in variables. Therefore, Principal Components Analysis (PCA) was done in order to get an overall assessment of the possible relations among environmental variables in the considered stations using the software package PAleotological STatistic (PAST) version 2.17c (Hammer et al., 2001).

\section{Results:-}

Snail sampling was carried out at twenty one sites in nine Lakes in Yamoussoukro. Only two connected sites lake VII (6 $\left.6^{\circ} 48^{\prime} 35^{\prime \prime} \mathrm{N} ; 5^{\circ} 16^{\prime} 29^{\prime \prime} \mathrm{W}\right)$ and V (649' 01" N; 6 $\left.49^{\prime} 01^{\prime \prime} \mathrm{W}\right)$ harbored P. acuta (Fig. 1). Shell of specimens recorded is sinister elongate-ovate, smooth, moderately lustrous and translucent, fine close-set lines of growth, nonperceptible spiral lines (Fig. 2). Whorls 5 is very large, regularly and rapidly increasing, the spire short and suture slightly impressed. The ear-shaped aperture is large, about $3 / 4$ total length of shell; outer lip thin, sharp; inner lip closely appressed to the columellar region completely closing the umbilical region; columellar plait somewhat twisted; parietal callus wide, columellar fold well marked. Largest shell $14 \mathrm{~mm}$ in length, $7 \mathrm{~mm}$ in width.
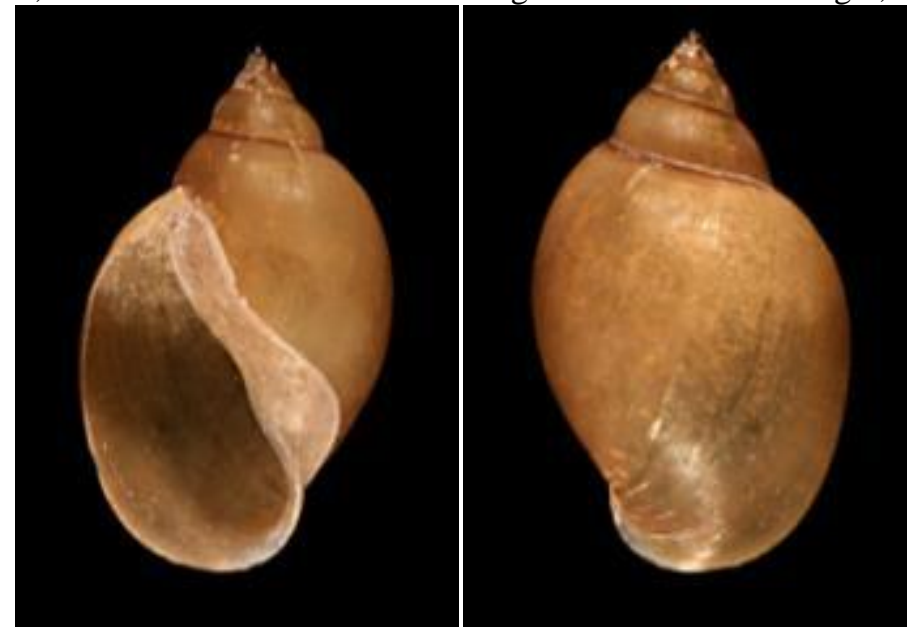

Fig. 2: Shells of Physa acuta from Yamoussoukro, Ivory Coast, ventral and dorsal view.

The reproductive system (Fig. 3) - Ovotestis (ot) embedded in the digestive gland. Ovotestis follicles emptying into a collecting canal which continues into the ovispermiduct (od). Between the proximal and distal segments of the 
latter are the seminal vesicles (sv). The ovispermiduct empties into the carrefour from which the oviduct (ov) emerges as a narrow tube which runs leftwards, gradually widens, becomes bosselated and highly convoluted, proceeding into the nidamental gland (ng). This latter shows no remarkable features and narrows to the uterus (ut) and vagina (va), which receives the spermathecal duct (sd), about twice as long as the spermatheca (sp). Immediately after emerging from the carrefour the spermiduct gives off a series of short prostatic diverticula (pr). They may be simple or divided into usually $2-4$ short branches. After giving off the last diverticulum the spermiduct continues into the vas deferens (vd), which opens into the caudal end of the penis. The penis sheath (ps) is somewhat swollen proximally, tapering gradually distalward and expanding into a sarcobellum at its junction with the prepuce. The prepuce (pp), much wider than the penis sheath, is from about as long to twice as long as the latter; a lenticular gland $(\mathrm{pg})$ is present on the proximal half of the preputial wall.

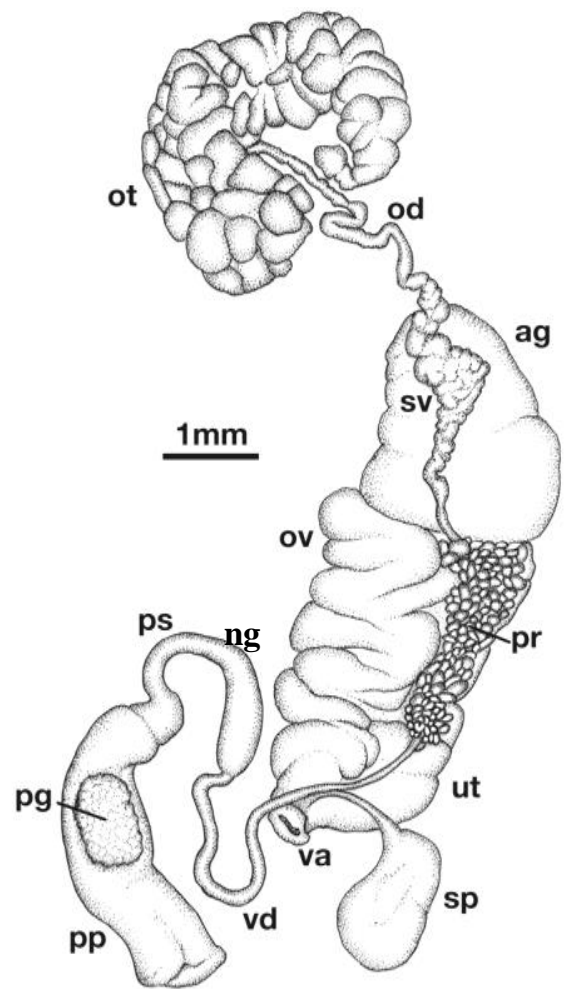

Fig. 3: Anatomy of the reproductive system of Physa acuta from Yamoussoukro, Ivory Coast: ot ovotestis, od ovispermiduct, ag albumen gland, sv seminal vesicles, ov oviduct, ng nidamental gland, pr prostate, pp preputium, ps penis sheath, sp spermatheca, va vagina, vd vas deferens, ut uterus, pg preputial gland.

Ordination of sampling stations on the Yamoussoukro man-made lake system in relation with environmental variables represented by a biplot diagram from the PCA is shown in figure 4. The percentage variance on the PCA axis 1 and 2 explained respectively $91.2 \%$ and $07.0 \%$ of variability in the physicochemical characteristics. These two axes explained together $98.2 \%$ of total variation. Axis 1 divided the stations in two groups: one group composed of all stations located on lake VII and one on lake V in the positive part and another group constituted of others sites in the negative part. This axis mainly represented a significant and positive gradient of conductivity, Total Dissolved Solides (TDS) and Fecal Coliforms. The results of PCA revealed that stations of the first group (lake VII and V) were associated with important amount of conductivity and TDS, and greater values of Fecal Coliforms. 


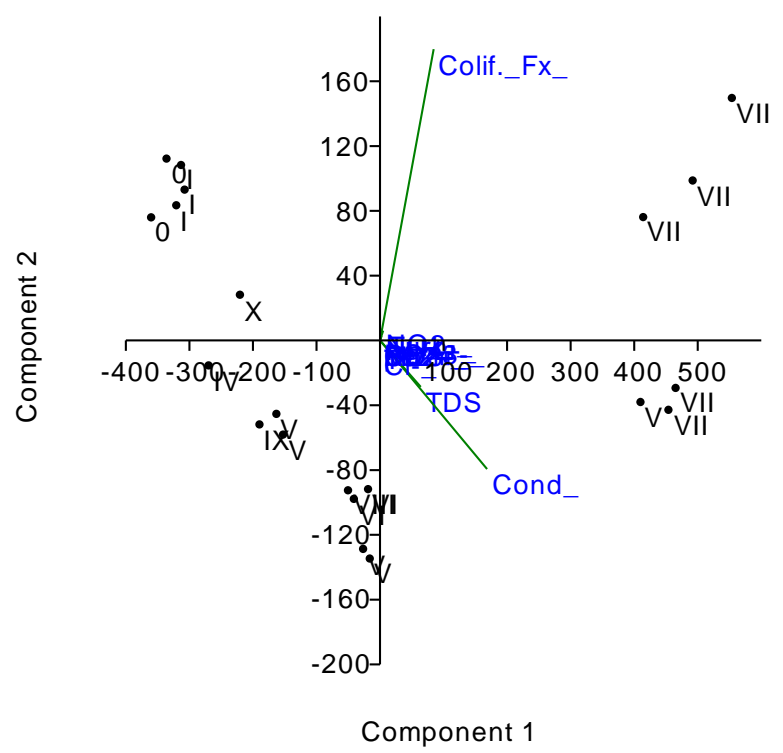

Fig. 4: A Principal Components Analysis (PCA) ordination biplot of the 16 environmental variables recorded for 7 sampling stations along the man-made lake system of Yamoussoukro (variance explained: PC1=91.2\%, PC2 $=07.0 \%)$. Cond=Conductivity, TDS= Total Dissolved Solides, Colif_Fx $=$ Fecal Coliforms; Roman numbers represented lakes.

\section{Discussion:-}

The morphology of physid snails collected from Yamoussoukro (Ivory Coast, West Africa) is clearly indistinguishable, in shell and anatomy. Shells showed all the characteristics of $P$. acuta as described by Brown (1994) and Paraense and Pointier (2003). Most major freshwater habitat types are prone to Physa acuta invasions (Meier-Brook, 2002), so far there has been no record of this species in Ivory Coast. From the results it clearly appears that $P$. acuta is present in this West African country. Though the occurrence seems to be restricted to the single disturbed lake VII yet, we consider it likely that the species will further spread via active and/or passive dispersal. It is known, for example, that $P$. acuta commonly occurs in roots of floating water plants (de Kock and Wolmarans, 2007) and thus rapidly spreads across large distances.

Our PCA results confirm the important role of physicochemical conditions of water for the community composition of macroinvertebrates. P acuta was associated to water with high level of conductivity and TDS, and greater values of Fecal Coliforms. P. acuta has been shown to be associated with polluted water (Brown 1994) and one common name of the species is "sewage snail". It was also demonstrated that $P$. acuta was responsible for rarefaction of the native Physa fontinalis in Italy (Manganelli et al., 2000). P. acuta is a prolific breeder and can survive in polluted waters. It has adapted to a wide range of environments, and therefore constitutes a relevant biological model for understanding how adaptation proceeds.

\section{Acknowledgments:-}

We are grateful to the "Société de Développement Touristique de la Région des Lacs" SODERTOUR LACS and its managing director for the support provided during this study in Yamoussoukro. The assistance of Jean Pierre Pointier for anatomic study is gratefully acknowledged.

\section{References:-}

1. Alexandrawicz, S.W. (1986). Physa acuta Draparnaud, 1805 (Mollusca, Gastropoda) from the recent Vistula sediments at Tyniec near Cracow. Acta Zool Cracov 29: 355-372.

2. Ali, J.H. (1993). The distribution of Physa acuta Draparnaud (Gastropoda: Physidae) in Malaysia and its suitability as test material for insecticide toxicity studies. J Med Appl Malacol 5: 129-134.

3. Appleton, C.C. (2003). Alien and invasive freshwater Gastropoda in South Africa. African Journal of Aquatic Sciences, 28: 69-81.

4. Appleton, C.C. and Baily, I.W. (1990). Canoeists and water borne diseases in South Africa, S Af Med J, 78 : 323-326. 
5. Brackenbury, T.D. and Appleton, C.C. (1993). Recolonization of the Umsindusi River, Natal, South Africa, by the invasive gastropod, Physa acuta (Basommatophora, Physidae). J Med Appl Malacol, 5: 39-44.

6. Brown, D.S. (1965). Freshwater gastropod Mollusca from Ethiopia. Bulletin of the British Museum (Natural History), Zoology, 12: 37-94.

7. Brown, D.S. (1980). Fresh Water Snails of Africa and Their Medical Importance, Taylor and Francis, London, $487 \mathrm{pp}$.

8. Brown, D.S. (1994). Freshwater Snails of Africa and their Medical Importance. Taylor \& Francis, London, $608 \mathrm{p}$.

9. Brown, D.S. and Wright, C.A. (1980). Molluscs of Saudi Arabia. Freshwater Molluscs. In Fauna of Saudi Arabia, 2: 341-358. Wittner, W. and Buttiker, W. (Eds). Basel: Basel Natural History Museum.

10. Brigoo, E.R. (1968). Les Bilharzioses humaines à Madagascar. In Santé et Dévellopement, $1^{\text {st }}$ Congrès Internationales des Sciences Médicales de Madagascar: 1-165.

11. Clark, F. and Baroudy, E. (1990). Studies on Laccocoris limigenus (Stal.) (Hemiptera: Naucoridae) in Lake Naivasha, Kenya. The Entomologist, 109: 240-249.

12. Clark, F. Beeby, A. and Kirby, P. (1989). A study of macro-invertebrates of Lakes Naivasha, Oloidien and Sonachi, Kenya. Revue d'Hydrobiologie Tropicale, 22: 21-33.

13. Curtis, B.A. (1991). Fresh water macro-invertebrates of Namibia. Madoqua 17: 163-187.

14. Binder, E. (1957). Mollusques aquatiques de Côte d'Ivoire. 1. Gastéropodes. Bulletin de l'Institut Fondamental d'Afrique Noire, 19: 97-125.

15. Burch, J.B. (Eds) (1985). Handbook on Schistosomiasis and Other Snail-Mediated Diseases in Jordan. Ann Arbor: University of Michigan.

16. De Clercq, D. (1987). La situation malacologique à Kinshasa et description d'un foyer autochtone de Shistosomiase à Schistosoma intercalatum. Annales de la Société Belge de Médecine Tropicale, 67 : 345-352.

17. De Kock, K.N., Joubert, P.H. and Pretorius, S.J. (1989). Geographical distribution and habitat preferences of the invader freshwater snail species Lymnaea columella in South Africa, Journal of Veterinary Research, 56: 271275.

18. De Kock, K.N. and Wolmarans, C.T. (2007). Distribution and habitats of the alien invader freshwater snail Physa acuta in South Africa. Water SA 33:717-722.

19. Dillon, R.T., Wethington, A.R., Rhett, J.M. and Smith, T.P. (2002): Populations of the European freshwater pulmonate Physa acuta are not reproductively isolated from American Physa heterostropha or Physa integra. Invertebrate Biology, 121: 226-234.

20. Dupouy, J. and Mimpfoundi, R. (1986). Cycle biologique de Biomphalaria pfeifferi (Krauss) dans les milieux anthropisés du district de Yaoundé (Cameroun). Comptes rendus de la Société de Biogéographie, Paris, 62: $47-$ 60.

21. Fashuyi, S.A. (1990). Freshwater gastropod molluscs in Ondo State, Nigeria. Journal of African Zoology, 104: 165-170.

22. Franc, A. (1949). Unionidae d'Afrique occidentale française recueillis par Théodore Monod, Journal de Conchyliologie, 99: 157-187.

23. Germain, L. (1908). Mollusques terrestres et fluviatiles recueillis par M.A. Chevallier à la Côte d'Ivoire (1907), Journal de Conchyliologie, 56: 95-115.

24. Germain, L. (1911). Contribution à la faune malacologique de l'Afrique Equatoriale, XXVI. Mollusques recueillis par M. le Lieutenant Lamolle à Querqué, sur la frontière française du Libéria. Bulletin du Museum d'Histoire Naturelle: 227-240.

25. Godan, D. (1983). Pest Slugs and Snails, Biology and Control, Springer-Verlag, Berlin, Heidelberg, New York, $445 \mathrm{pp}$.

26. Hammer, O., Harper, D.A.T. and Ryan, P.D. (2001). Paleontological Statistics Software Package for Education and Data Analysis. Paleontologica Electronica, 4(1):1-9.

27. Hamilton-Atwell, V.L., De Kock, K.N. and Van Eeden, J.A. (1970). The occurrence end distribution of Physa acuta Draparnaud in the Republic of South Africa. Wetenskaplike Bydraes van die Potchefstroomse Universiteit, B, Natuurwetenskappe, 26: 11 pp.

28. Kristensen, T.K. and Ogunnowo, O. (1992). Physa acuta Draparnaud, 1804 recorded from Nigeria, Jounal of Molluscan Studies, 58: 228-229.

29. Macha, S. (1971). Kultureinflusse auf die Molluskenfauna. Tschech Casop Acta Musci Silesiae, Ser A, Sci Nat, 20: 121-146. 
30. Mandahl-Barth, G., Ripert, C. and Raccurt, C. (1974). Nature du sous-sol répartition des mollusques dulçaquicoles et foyers de bilharzioses intestinale et urinaire au Bas-Zaïre. Revue de Zoologie Africaine, 88: 553-584.

31. Madsen, H. and Frandsen, F. (1989). The spread of freshwater snails including those of medical and veterinary importance. Acta Tropica, 46: 139-146.

32. Magzoub, M. and Kassim, A.A. (1980). Schistosomiasis in Saudi Arabia. Annals of tropical Medecine and Hygiene, 74: 511-513.

33. Manganelli, G., Bodon, M., Cianfanelli, S., Favilli, L and Giusti, F., (2000). Conoscenza e conservazione dei molluschi non marini italiani: lo stato delle ricerche. Boll Malacol 36: 5-42.

34. Meier-Brook, C. (2002). What makes an aquatic ecosystem susceptible to mollusc invasions? In: Falkner M, Groh K, Speight MCD (eds) Collectanea malacologica: Festschrift für Gerhard Falkner. ConchBooks, Hackenheim, pp 405-417.

35. Mouchet, F., Rey, J.L. and Cunin, P. (1987). Découverte d'Indoplanorbis exustus (Planorbidae, Bulininae) à Yamossoukro, Côte d'Ivoire, Bulletin de la Société de Pathologie Exotique, 80: 811-812.

36. Ndamkou, C. (1985). Les gastéropodes d'eau douce de la région de Bouaké (Côte d'Ivoire): faunistique et intérêt médical. Diplôme d'Etudes Approfondies, Université d'Abidjan.

37. N'goran, E.K. (1997). Biodiversité, transmission et épidémiologie de Schistosoma haematobium, Bilharz, 1852 et des schistosomes apparentés en Côte d'Ivoire. Thèse de doctorat, Université de Perpignan.

38. Paraense, W.L. (2005). Planorbidae, Lymnaeidae and Physidae of Argentina (Mollusca: Basommatophora). Memorias do Instituto Oswaldo Cruz, Rio de Janeiro, 100(5): 491-493.

39. Paraense, W.L. and Pointier, J.P. (2003). Physa acuta Draparnaud, 1805 (Gastropoda: Physidae): A study of topotypic specimens. Memorias do Instituto Oswaldo Cruz, 98: 513-517.

40. Raut, S.K., Bhaumik, S., and Das, S. (1995). Occurrence of the snail Physa acuta Draparnaud in Calcutta, India. J. Bombay Nat. Hist. Soc. 92: 434.

41. Taylor, D.W. (2003): Introduction to Physidae (Gastropoda: Hygrophila); biogeography, classification, morphology,.Rev Biol Trop, 51:1-263.

42. Tchernov, E. (1971). Freshwater mollusks of the Sinaï peninsula, Israel Journal of Zoology, 20: $209-221$.

43. Yapi, Y. (1988). Situation épidémiologique de la schistosomose intestinale à Schistosoma mansoni Sambon, 1907 en zone humide de Côte d'Ivoire (région de Man). Thèse de doctorat de $3^{\text {ème }}$ cycle, Université Nationale de Côte d'Ivoire. 